\title{
Squamous Cell Carcinoma of the Thyroid: An Aggressive Tumor Associated with Tall Cell Variant of Papillary Thyroid Carcinoma
}

\author{
Celina G. Kleer, M.D., Thomas J. Giordano, M.D., Ph.D., Maria J. Merino, M.D. \\ Department of Pathology, University of Michigan Medical Center (CGK, TJG), Ann Arbor, Michigan and \\ Laboratory of Pathology, National Cancer Institute (MJM), Bethesda, Maryland
}

\begin{abstract}
Squamous cell carcinoma of the thyroid (SCT) is an unusual neoplasm thought to arise as a primary tumor or as a component of an undifferentiated carcinoma. The role of $\mathrm{p53}$ and $\mathrm{Ki}-67$ as prognostic indicators in this type of tumor is not known. We studied eight cases of primary SCT. Three cases were analyzed for Ki-67 by immunohistochemistry and for p53 by immunohistochemistry and loss of heterozygosity. Seven patients were women, and one was a man (age range, 31 to 90 years). SCT were firm, were tan with areas of necrosis, and ranged in size from 2 to $8 \mathrm{~cm}$. Histologically, they had islands of squamous cells with spindle cell areas (two of eight). In four of eight cases, SCT was associated with the tall cell variant of papillary carcinoma (TCV). Positive staining for p53 was seen in two of three cases, and in one of three the TCV was also positive for p53. Mean MIB1 labeling index was $30 \%$ and $17 \%$ in SCT and TCV, respectively. At the time of presentation, six of eight patients had cervical lymph node metastases. In one case, the primary tumor had SCT and TCV; however, only the SCT component metastasized. After mean follow-up of 48 months, one patient had died of disease, five were alive with recurrent or metastatic tumor, and two were lost to follow-up. Primary SCT is an aggressive neoplasm that may be found in association with TCV. p53 expression and high MIB1 labeling index occur in these tumors and may be useful prognosticators.
\end{abstract}

KEY WORDS: Squamous cell carcinoma, Tall cell variant, Thyroid neoplasms.

Mod Pathol 2000;13(7):742-746

Copyright () 2000 by The United States and Canadian Academy of Pathology, Inc.

VOL. 13, NO. 7, P. 742, 2000 Printed in the U.S.A

Date of acceptance: January 28, 2000.

Address reprint requests to: Dr. Celina G. Kleer, Department of Pathology 2G332, University of Michigan Hospitals, 1500 E. Medical Center Drive,

Ann Arbor, MI 48109-0054; e-mail: kleer@umich.edu.
Squamous cell carcinoma of the thyroid gland (SCT) is an unusual tumor with only a few reported cases. According to classic literature, it is thought to arise in two settings: as a primary tumor or as a component of an anaplastic or undifferentiated thyroid carcinoma, often mixed with heterologous elements and usually associated with areas of welldifferentiated papillary or follicular carcinoma.

The tall cell variant of papillary carcinoma (TCV), first described by Hawk and Hazard (1), is defined by the presence of neoplastic cells having a height that is at least twice the width in an otherwise typical papillary carcinoma. Several investigators found the TCV to have a more aggressive behavior than ordinary well-differentiated papillary carcinoma $(2,3)$.

We and others (4) have noticed that most cases of SCT are associated with TCV. However, it is not known whether the presence of an SCT component connotes a worse prognosis. In addition, the role of p53 and Ki-67 expression in these tumors is not known.

In the present study, we reviewed the histologic features of our cases of SCT and investigated whether detection of p53 tumor suppressor gene and Ki-67 antigen by immunohistochemistry and loss of heterozygosity (LOH) analysis are helpful prognosticators.

\section{MATERIALS AND METHODS}

Eight cases of primary SCT were studied. Five of the cases were obtained by reviewing the surgical pathology material of more than 200 cases of thyroid carcinomas at the Laboratory of Pathology, National Institutes of Health. Three cases were obtained from the surgical pathology files at the University of Michigan Medical Center. Hematoxylin and eosin-stained slides of all tumors were available. Cases were diagnosed as primary SCT when $75 \%$ or more of the tumor was composed of SCT. 
Clinical data and follow-up information were obtained by reviewing the patients' charts.

\section{Immunohistochemical Analysis}

Immunohistochemistry was performed on three cases on 5- $\mu$-thick paraffin sections with monoclonal antibodies against Ki-67 (MIB1; Zymed, San Francisco, CA; 1:50 dilution) and p53 (Oncogene, Boston, MA; 1:20 dilution), using the streptavidinbiotin-peroxidase method (ABC kit, Vectastain Elite; Vector Lab, Burlingame, CA). Briefly, sections were deparaffinized and hydrated. To block endogenous peroxidase, they were incubated in a $0.3 \%$ solution of hydrogen peroxide in phosphate buffered saline (PBS) and incubated overnight with primary monoclonal antibody. Subsequently, biotinylated rabbit antimouse immunoglobulin (secondary antibody) and avidin-biotin-complex with horseradish peroxidase were applied, followed by addition of 3,3'-diaminobenzidine tetrahydrochloride and copper enhancer. Slides were counterstained with hematoxylin. To quantify the tumors' proliferative activity, sections were studied at high power $(\times 400)$, and 8 to 10 fields were assessed randomly, expressing the number of cells with positive nuclear staining as a percentage (MIB1 labeling index [LI]). Internal positive control staining was seen in normal tissue, such as lymphocytes, endothelial cells, and fibroblasts.

\section{LOH Analysis}

LOH analysis for TP53 (17p13) using polymerase chain reaction (PCR) was performed in three cases. Microdissection of selected areas was performed under direct light microscope visualization, as has been previously described (5). Briefly, unstained formalin-fixed, paraffin-embedded 5 - $\mu$-thick tissue sections were prepared on glass slides, deparaffinized, and air dried. The prior section was stained with hematoxylin and eosin. Tumor and normal cells were selected from each air-dried slide and microdissected using a disposable, 30-gauge needle. Procured cells were immediately resuspended in a $20-\mathrm{mL}$ solution containing $50 \mathrm{~mm}$ Tris ( $\mathrm{pH}$ 8.5), $1 \mathrm{~mm}$ ethylenediamine tetraacetic acid (EDTA) (pH 8.0), and 0.5\% Tween (Sigma, St. Louis, MO), $10 \mathrm{mg} / \mathrm{mL}$ proteinase $\mathrm{K}\left(\mathrm{pH}\right.$ 8.0) and incubated for $72 \mathrm{~h}$ at $60^{\circ} \mathrm{C}$. The mixture was then boiled for 5 min to inactivate proteinase $\mathrm{K}$, and $1.5 \mu \mathrm{L}$ of this solution was used for PCR analysis. Tumor and normal DNA from each case was subjected to heating for $9 \mathrm{~min}$ at $95^{\circ} \mathrm{C}$ followed by 35 cycles of PCR under the following conditions: $60^{\circ} \mathrm{C}$ for $2 \mathrm{~min}, 94^{\circ} \mathrm{C}$ for $1 \mathrm{~min}$, followed by an extension step of 1 cycle at $72^{\circ} \mathrm{C}$ for $5 \mathrm{~min}$. PCR was performed in $10 \mu \mathrm{L}$ reactions containing $1 \mu \mathrm{L} 10 \times$ PCR buffer (100 mmol/L Tris-HCL, pH 8.3 (at 25 C); $500 \mathrm{~mm} \mathrm{KCL;}$
$15 \mathrm{~mm} \mathrm{MgCl}_{2} ; 0.01 \%$ gelatin), $0.8 \mu \mathrm{L} 20$-mm concentration of each deoxycytidine triphosphate, deoxyguanosine triphosphate, deoxythymidine triphosphate, and deoxyadenosine triphosphate; $5.6 \mu \mathrm{L}$ millipore water; $0.4 \mu \mathrm{L} 50 \mathrm{pm}$ of each primer; $0.2 \mu \mathrm{L}$ [32P] deoxycytidine triphosphate $(6000 \mathrm{Ci} / \mathrm{mmol} / \mathrm{L})$; and 0.1 unit of Taq DNA polymerase (AmpliTaq Gold, 250 U, 5 U/mL; Perkin Elmer, Norwalk, CT). Labeled amplified DNA was mixed with an equal volume of formamide sample buffer ( $238 \mathrm{~mL}$ formamide, $0.25 \%$ of bromophenol blue, $0.25 \%$ of xylene cyanol, and 12 mм EDTA pH 8.0). The samples were denatured for 5 min at $94^{\circ} \mathrm{C}$ and loaded onto a gel consisting of $6 \%$ acrylamide. Samples were electrophoresed at $1800 \mathrm{~V}$ for $2 \mathrm{~h}$, and gels were transferred to 3-mm Whatman paper and dried for $1 \mathrm{~h}$ at $80^{\circ} \mathrm{C}$, and autoradiography was performed with Kodak X-OMAT film (Eastman Kodak, Rochester, NY). A locus was considered informative for a particular patient when the constitutional DNA from that patient displayed two different alleles (heterozygous at that locus), and $\mathrm{LOH}$ was present when one of the two polymorphic alleles present in the normal tissue DNA was absent or reduced in the tumoral DNA by at least $70 \%$.

\section{RESULTS}

Table 1 summarizes the clinical and pathologic findings. The eight patients were seven women and one man. The mean age was 64 years (range, 31 to 90 years). Tumors were large, ranging from 2 to 8 $\mathrm{cm}$ (mean, $5 \mathrm{~cm}$ ). Six tumors arose in the right lobe, and two arose in left lobe. They were described as tan-gray, with firm consistency and large areas of necrosis. In two cases, hemorrhage was also noted. Histologically, the SCT were similar to those arising in other locations. They were composed of islands of squamous cells with varying degrees of differentiation (Figure 1). A spindle cell component of the SCT was seen in two cases. In addition to the SCT,

TABLE 1. Clinical Features of Patients with Primary Squamous Cell Carcinoma of the Thyroid

\begin{tabular}{|c|c|c|c|c|c|}
\hline Patient & Age & Sex & Site & Tumor Spread & $\begin{array}{c}\text { Follow- } \\
\text { Up }\end{array}$ \\
\hline 1 & 64 & M & $\mathrm{R}$ & Local invasion & Lost \\
\hline 2 & 66 & $\mathrm{~F}$ & $\mathrm{R}$ & Local invasion & Lost \\
\hline 3 & 38 & $\mathrm{~F}$ & $\mathrm{~L}$ & $\begin{array}{l}\text { Local invasion } \\
\text { LN metastasis }\end{array}$ & AWD \\
\hline 4 & 90 & $\mathrm{~F}$ & $\mathrm{~L}$ & $\begin{array}{l}\text { Local invasion } \\
\text { LN metastasis }\end{array}$ & DOD \\
\hline 5 & 74 & $\mathrm{~F}$ & $\mathrm{R}$ & $\begin{array}{l}\text { Local invasion } \\
\text { LN metastasis }\end{array}$ & AWD \\
\hline 6 & 78 & $\mathrm{~F}$ & $\mathrm{R}$ & $\begin{array}{l}\text { Local invasion } \\
\text { LN metastasis }\end{array}$ & AWD \\
\hline 7 & 74 & $\mathrm{~F}$ & $\mathrm{R}$ and $\mathrm{L}$ & $\begin{array}{l}\text { Local invasion } \\
\text { LN metastasis }\end{array}$ & AWD \\
\hline 8 & 31 & $\mathrm{~F}$ & $\mathrm{R}$ and isthmus & $\begin{array}{l}\text { LN and lung } \\
\text { metastases }\end{array}$ & AWD \\
\hline
\end{tabular}

LN, lymph node; AWD, alive with disease; DOD, dead of disease. 


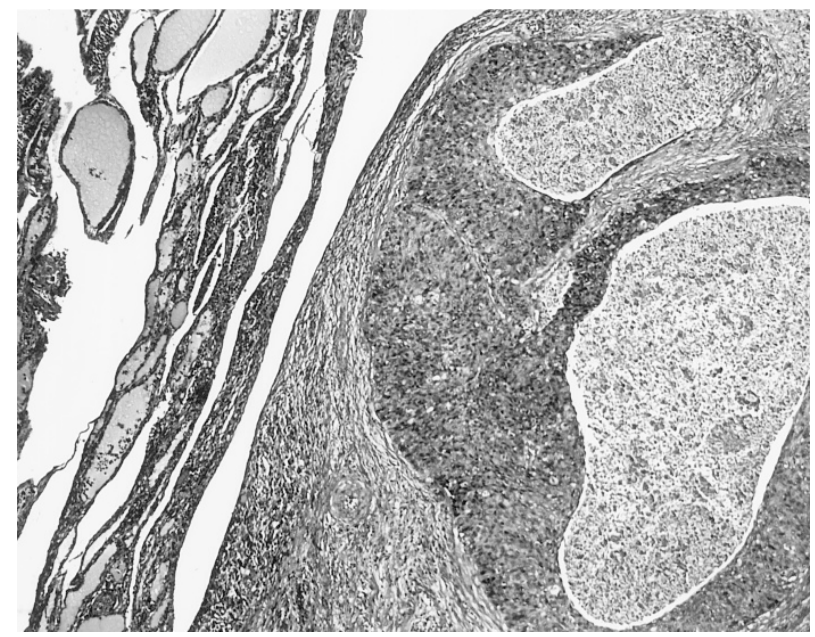

FIGURE 1. Infiltrating nests of squamous cell carcinoma of the thyroid with central necrosis.

two tumors contained areas of ordinary welldifferentiated papillary carcinoma, and four had areas of TCV. The tall cell component displayed intricate, well-formed long papillae, lined by tall columnar cells with abundant eosinophilic cytoplasm and basally located nuclei (Figure 2). It is interesting that the squamous islands merged imperceptibly with the TCV. Multinucleated giant cells were present in all tumors.

At the time of diagnosis, all patients had extensive local invasion with extrathyroidal extension of the tumor into surrounding soft tissues (Figure 3). One tumor had perineural invasion, and two showed extensive vascular invasion. Six patients had cervical lymph node metastases, and one patient had mediastinal involvement at presentation. It is interesting that in one of the cases, the primary tumor consisted of SCT and TCV; however, only the SCT component metastasized. After a mean follow-up of 48 months,

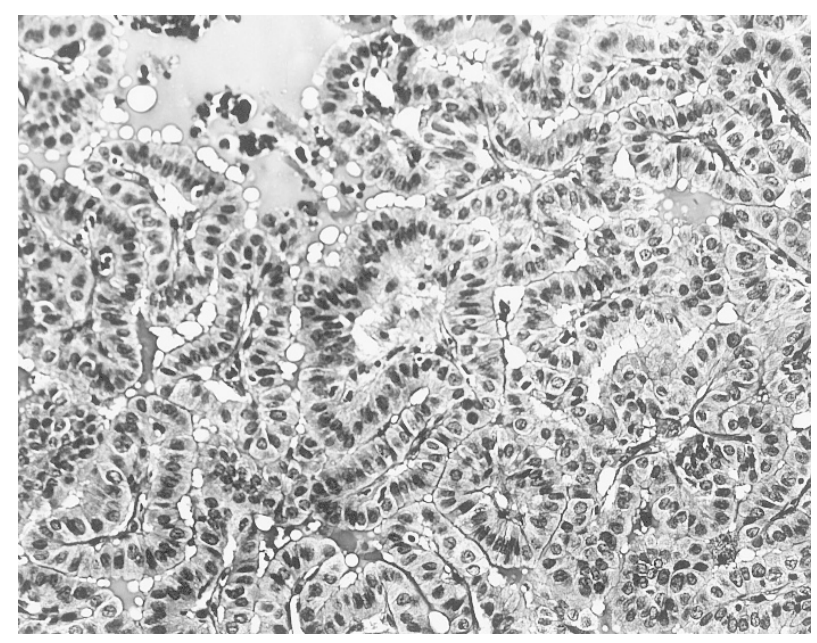

FIGURE 2. Tall cell papillary carcinoma displaying intricate, wellformed long papillae lined by tall columnar cells. The nuclei have the classic features of papillary carcinoma with chromatin clearing and occasional nuclear grooves and pseudoinclusions.

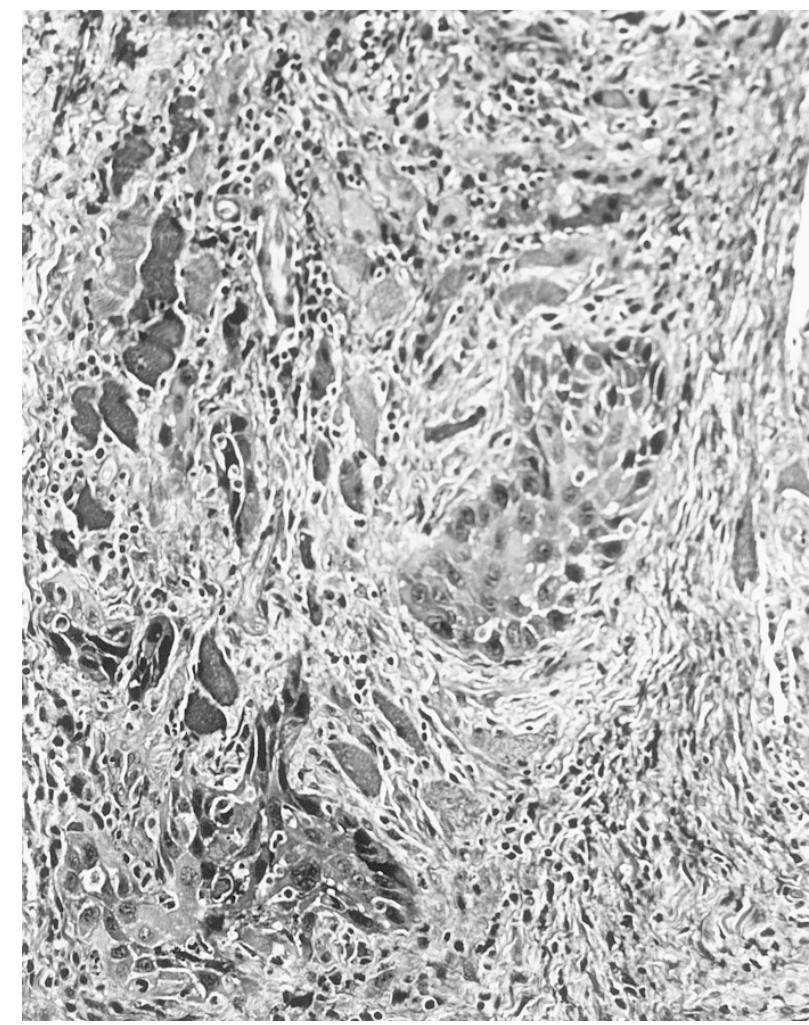

FIGURE 3. Squamous cell carcinoma of the thyroid invading perithyroidal skeletal muscle.

one patient had died of disease, five were alive with recurrent or metastatic tumor, and two were lost to follow-up (Table 1).

\section{Immunohistochemistry and LOH Analysis}

Two of three tumors stained positively for p53. In one of three cases, the TCV area was also positive for p53. One of the three cases showed allelic deletion at the TP53 locus (17p13) (see Table 2). The mean MIB1 LI was $30 \%$ and $17 \%$ in SCT and TCV components in the same tumors, respectively.

\section{DISCUSSION}

Primary SCT is an uncommon neoplasm with few cases reported in the literature. Some authors con-

TABLE 2. Summary of Histologic Features, LOH for p53, and p53 Immunostaining

\begin{tabular}{ccll}
\hline Patient & $\begin{array}{c}\text { Papillary } \\
\text { Component }\end{array}$ & $\begin{array}{c}\text { LOH } \\
\text { TP53 }\end{array}$ & \multicolumn{1}{c}{ p53 } \\
\hline 1 & UTPC & NA & NA \\
2 & - & NA & NA \\
3 & UTPC & NA & NA \\
4 & TCV & NA & NA \\
5 & TCV & NA & NA \\
6 & TCV & No LOH & Positive \\
7 & TCV & LOH & Positive \\
8 & - & No LOH & Negative \\
\hline
\end{tabular}

LOH, loss of heterozygosity; UTPC, usual type papillary carcinoma; $\mathrm{TCV}$, tall cell variant of papillary carcinoma; NA, not performed. 
sider this tumor a form of anaplastic or undifferentiated thyroid carcinoma. Until now, little has been known about the origin and behavior of this neoplasm and whether there are any prognostic indicators.

The presence of squamous cells in the thyroid gland has long been recognized (6-8). LiVolsi and Merino (8) suggested that in most cases they appear as a result of metaplasia of follicular epithelial cells. The authors recognized that squamous areas may be seen in approximately $40 \%$ of papillary carcinomas. Gould et al. (9) analyzed six papillary thyroid carcinomas by electron microscopy and found cells with abundant cytoplasmic protein filaments. However, keratohyline granules were not present. They suggested that these cells represented altered follicular epithelial cells.

Most of the reported cases in the literature contained both SCT and adenocarcinoma and were interpreted as collision tumors. Authors used the term adenoacanthoma, suggesting that the squamous component was derived from a metaplastic process. These patients had a uniformly poor prognosis with few months' survival $(6,10)$. Over the years, we and others (4) have noticed that the occurrence of SCT is accompanied by the presence of TCV.

The TCV was first described by Hawk and Hazard (1). It is characterized by the presence of acidophilic cells having a height that is at least twice the width (Figure 2). These tumors tend to be larger and occur in older patients than the usual papillary thyroid carcinoma (UPTC). In addition, the TCV was found by several investigators to follow a more aggressive course than UPTC. Johnson et al. (2) studied 12 patients with TCV, obtained from reviewing more than 300 cases of papillary thyroid carcinoma accessioned at the University of Michigan Medical Center between 1972 and 1986, and compared clinical and pathologic parameters against 12 control patients with UTPC. They found that TCV was a more aggressive neoplasm with a worse prognosis.

In this study, we present eight cases of primary SCT. The histology of these neoplasms is characterized by well-defined nests of squamous cells with varying degrees of differentiation that in two cases merge imperceptibly with TCV. The peculiar association between SCT and TCV has been noted previously (4). Bronner and LiVolsi (4) studied five cases of spindle cell SCT associated with TCV. Histologically, the tumors were composed of a mixture of TCV and islands of spindled, malignant squamous cells. The authors suggested that this association was not coincidental and may represent a histopathologic link in the development of thyroid carcinogenesis.
In Bronner and LiVolsi's study, the five tumors composed of SCT and TCV behaved in an aggressive fashion. All five cases had extrathyroidal extension, two tumors invaded the trachea, and four had vascular invasion. These results are supported by the present study, in which all eight cases of primary SCT had extension in perithyroidal soft tissues of the neck, with prominent vascular invasion (two cases) and perineural invasion (one case). In addition, mediastinal lymph node metastasis developed in one case. It is interesting that in one patient, the metastatic deposits were composed of pure SCT. We did not find any differences in tumor behavior among pure SCT (two cases), SCT mixed with TCV (four cases), and SCT associated with UTPC (two cases). These results suggest that the presence of SCT component, whether alone or in association with TCV or UTPC, predicts a dismal prognosis.

The main differential diagnosis of primary SCT is with squamous cell carcinoma extending into or metastasizing to the thyroid gland from the larynx, esophagus, nasopharynx, or lung. In the two patients who in this study had pure SCT, no other primary site was identified despite extensive workup.

The role of p53 and MIB1 as prognostic indicators in this type of neoplasm has not been investigated. $p 53$ is a tumor suppressor gene found to be mutated in approximately half of almost all types of cancers, including leukemias; lymphomas; and colorectal, ovarian, and lung carcinomas (11-17). Immunohistochemical detection of the $\mathrm{p} 53$ protein is dependent on the increased half-life of the mutated p53 protein (18-20). In the present study, the SCT component in the three cases analyzed by immunohistochemistry were positive for p53 protein. The TCV area in one of three cases was also positive. These results are in agreement with a previous report, which showed that positive staining for p53 is found in poorly differentiated and undifferentiated thyroid carcinomas (15). Nishida et al. (21) reported that $18 \%$ of well-differentiated carcinomas and $56 \%$ of poorly differentiated carcinomas stained positively for the p53 protein. In addition, they found a correlation between positive p53 staining and postoperative local recurrence. Another study (13) found p53-positive staining in $12 \%$, $41 \%$, and $64 \%$ of well-differentiated, poorly differentiated, and undifferentiated carcinomas, respectively.

The role of $p 53$ as a tumor suppressor gene is explained by loss of one p53 allele and mutation of the other $(14,19)$. However, in some tumors, a mutant p53 allele is coexpressed with wild-type p53 and exerts a dominant negative effect. We found that one of three SCT showed LOH for the chromosome $17 \mathrm{p}$ marker TP53, which is closely adjacent to the $p 53$ gene. These results suggest that $\mathrm{LOH}$ in 
17 p13 may not be a useful marker of tumor aggressiveness in these thyroid neoplasms.

Tumor proliferative activity has been studied for a variety of neoplasms (22-27) and seems to provide important biologic information that correlates with tumor recurrence and patients' survival. In the present study, the MIB1 LI was higher in the squamous cell carcinoma component than in the TCV component. These results suggest that there is a spectrum of malignancy and aggressiveness in these thyroid neoplasms.

In summary, primary SCT is a highly aggressive neoplasm that may be found in association with TCV. Detection of p53 and Ki-67 by immunohistochemistry may be useful prognosticators.

\section{REFERENCES}

1. Hawk WA, Hazard JB. The many appearances of papillary carcinoma of the thyroid. Cleve Clin Q 1976;43:207-16.

2. Johnson T, Lloyd RV, Thompson NW, Bierwaltes WH, Sisson JC. Prognostic implications of the tall cell variant of papillary thyroid carcinoma. Am J Surg Pathol 1988;12(1):22-7.

3. Ostrowski ML, Merino MJ. Tall cell variant of papillary thyroid carcinoma: a reassessment and immunohistochemical study with comparison to the usual type of papillary carcinoma of the thyroid. Am J Surg Pathol 1996;20(8):964-74.

4. Bronner MP, LiVolsi VA. Spindle cell squamous carcinoma of the thyroid: an unusual anaplastic tumor associated with tall cell papillary cancer. Mod Pathol 1991;4:637-43.

5. Zhuang Z, Berttheau P, Emmert-Buck MR, Liotta LA, Gnarra $\mathrm{J}$, Linehan WM, et al. A new microdissection technique for archival DNA analysis of specific cell populations in lesions less than one millimeter. Am J Pathol 1995;146:620-5.

6. Prakash A, Kukreti SC, Sharma MP. Primary squamous cell carcinoma of the thyroid gland. Int Surg 1968;50(6):538-41.

7. Goldberg HM, Harvey P. Squamous cell cysts of the thyroid. Br J Surg 1956;43:565-9.

8. LiVolsi VA, Merino MJ. Squamous cell in the human thyroid gland. Am J Surg Pathol 1978;2:133-40.

9. Gould VE, Gould NS, Benditt EP. Ultrastructural aspects of papillary and sclerosing carcinomas of the thyroid. Cancer 1972;29:1613-25.

10. Motoyama T, Watanabe H. Simultaneous squamous cell carcinoma and papillary adenocarcinoma of the thyroid gland. Hum Pathol 1983;14:1009-10.

11. Baker SJ, Fearon ER, Nigro J, Hamilton S, Preisinger AC, Jessup JM, et al. Chromosome 17 deletions and p53 gene mutations in colorectal carcinomas. Science 1989;244:21721.

12. Baker SJ, Preisinger AC, Jessup JM, Paraskeva C, Markowitz $\mathrm{S}$, Wilson JK, et al. p53 gene mutations occur in combination with 17p allelic deletions as late events in colorectal tumorigenesis. Cancer Res 1990;50:7717-22.

13. Dobashi Y, Sakamoto A, Sugimura H, Mernyei M, Mori M, Oyama T, et al. Overexpression of p53 as a prognostic factor in human thyroid carcinoma. Am J Surg Pathol 1993;17:37581.

14. Harris CC, Hollstein M. Clinical implications of the p53 tumor-suppressor gene. N Engl J Med 1993;329:1318-27.

15. Ito T, Seyama T, Mitzuno T, Tsuyama N, Hayashi T, Hayashi $\mathrm{Y}$, et al. Unique association of p53 mutations with undifferentiated but not with differentiated carcinomas of the thyroid gland. Cancer Res 1992;52:1369-71.

16. Lane DP. p53 and human cancers. Br Med Bull 1994;50:58299.

17. Levine AJ, Momand J, Finlay CA. The p53 tumour suppressor gene. Nature 1991;351:453-6.

18. Banks L, Matlashewski G, Crawford L. Isolation of human p53-specific monoclonal antibodies and their use in the studies of human p53 expression. Eur J Biochem 1986;159: 529-34.

19. Gannon JV Jr, Iggo R, Lane DP. Activating mutations in p53 produce a common conformational effect: a monoclonal antibody specific for the mutant form. EMBO J 1990;9:1595602.

20. Michalovitz D, Halevy O, Oren M. p53 mutations: gains or losses? J Cell Biochem 1991;45:22-9.

21. Nishida T, Nakao K, Hamaji M, Nakahara M, Tsujimoto M. Overexpression of p53 protein and DNA content are important biologic prognostic factors for thyroid cancer. Surgery 1996;119:568-75.

22. Barbareschi M, Girlando S, Mauri FM, Forti S, Eccher C, Mauri FA, et al. Quantitative growth fraction evaluation with MIB1 and Ki-67 antibodies in breast carcinomas. Am J Clin Pathol 1994;102:171-5.

23. Fielding LP, Fenoglio-Preiser C, Freedman LS. The future of prognostic factors in outcome prediction for patients with cancer. Cancer 1992;70:2367-77.

24. Khine MM, Aung W, Sibbons PD, Howard CV, Clapham E, McGill F, et al. Analysis of relative proliferation rates of Wilms' tumor components using proliferating cell nuclear antigen and MIB1 (Ki-67 equivalent antigen) immunostaining and assessment of mitotic index. Lab Invest 1994;70: $125-9$.

25. Stavropoulos NE, Ioackim-Velogianni E, Hastazeris K, Kitsiou E, Stefanaki S, Agnantis N. Growth factors in bladder cancer defined by Ki-67: association with cancer grade, category and recurrence rate of superficial lesions. Br J Urol 1993;72:736-9.

26. Weidner N, Moore II DH, Vartanian R. Correlation of Ki-67 antigen expression with mitotic figure index and tumor grade in breast carcinomas using the novel "paraffin"reactive MIB1 antibody. Hum Pathol 1994;25:337-42.

27. Wintzer HO, Zipfel I, Schulte-Monting J, Hellerich U, von Kleist S. Ki-67 immunostaining in human breast tumors and its relationship to prognosis. Cancer 1991;67:421-8. 